nhận trường hợp nào mắc hội chứng Edwards và hội chứng Patau. Theo các nghiên cứu, hội chứng Edwads là hội chứng bất thường nhiễm sắc thể 18 có tỉ lệ mắc là $1 / 3000$, thường gặp ở thai gái, tỉ lê 4 gái/1 trai [7]. Có $80 \%$ các trường hợp hội chứng Edwards là ba nhiễm sắc thể 18 thuần, $10 \%$ là thể khảm và $10 \%$ là do chuyển đoạn nhiễm sắc thể 18 [8]. Tần suất xuất hiện hội chứng Patau là $1 / 10000$, nguyên nhân do thừa 1 NST 13. 95\% các thai mắc hội chứng Patau sẽ thành thai lưu, chỉ $5 \%$ trường hợp được sinh ra, tuy nhiên trên $90 \%$ các trường hợp này sẽ tử vong trong năm đầu do các dị tật bẩm sinh nặng nề) [9].

\section{KẾT LUẬN}

Tuổi trung bình của thai phụ nguy cơ cao là $38,45 \pm 5,87$. Độ tuổi thai phụ gặp nhiêu nhất trong nghiên cứu là $>37,5$ tuổi, chiếm $70,7 \%$. Khoảng sáng sau gáy trong nghiên cứu đa số trong khoảng $<2,5 \mathrm{~mm}$, chiếm $80,9 \%$. Từ $2,5-$ $3 \mathrm{~mm}$ chiếm $9,8 \%$. Từ $3 \mathrm{~mm}$ trở lên chiếm 9,3\%.

Thai bất thường NST chiếm 13/225 = 5,8\%. Trong số các thai có bất thường NST, thì thai hội chứng Down chiếm tỷ lệ cao nhất với 13/225 = $5,8 \%$. Không có trường hợp nào mắc hội chứng Edwards và hội chứng Patau.

\section{TÀI LIÊU THAM KHẢO}

1. Waild, JN, Anne $K$, Allan $H$, Ali M. Antenatal screening Down's syndrome, Journal of screening. 1997; 4: 181- 246.

2. Dungan, Jeffrey S, Elias, Sherman Prenatal Diagnostic Testing. The Merck Manuals Online Medical Liary. Archived from the original on 4 August 2010. Retrieved July. 2008; 30: 2010.

3. ACOG committee on Practice Bulletins ACOG Practice Bulletins No. 77: Screening for fetal chromosal abnormalities. Obtest Gynecol. 2007; 109: 217- 227.

4. Phan Xuân Diêp, Pham Thi Mai. Sàng loc thai hội chứng Down tại khoa phụ sản bệnh viện Đại hoc Y dược thành phố Hồ Chí Minh từ 110/2009 đến tó/2012, Tạp chíy học thành phố Hồ Chí Minh, 5. 2012: 15-22.

5. Hoàng Thu Lan. Hoàn chỉnh kỹ thuât lai tai chỗ huỳnh quang trong chẩn đoán trước sinh hội chứng Down. Luân văn thac sĩ Y hoc, Hà Nôi. 2004.

6. Lê Thanh Thuý. Đ̇ánh giá kết quả chọc hút nước ối để phân tích NST phát hiện dị tật của thai nhi tai bênh viên phu sản Hà Nồi và phu sản trung ương, Luận văn tổt nghiệp bác sĩ chuyển khoa cấp 2, Hà Nội. 2009.

7. Sybert VP, Mc Cauley E. Turner's syndrome. N Engl J Med. 2004; 351 (12): 1227- 1238.

8. Tartaglia NR, Howell $S$, Surtherland $A$, Wilson $R$, Wilson $L$. A review of trisomy $X$ (47XXX) . Orphanet J Rare Dis. 2010; 5(1):8.

9. Park JH, et al. Effects of sex chromosome aneuploidy on male sexual behavior. Genes Brain Behav. 2008; 7(6): 609- 617.

\title{
THƯC TRANG LOÉT ÁP LỰC VÀ MộT SỐ YẾU TỐ LIÊN QUAN ĐẾN NGƯỜI BỆNH HÔN MÊ TẠI KHOA HỒI SỨC TÍCH CỰC VÀ CHỐNG ĐộC BÊ̂NH VIÊ̂N ĐA KHOA TRUNG ƯO'NG CẦN THO'
}

\section{TÓM TẮT}

Nghiên cứu mô tả tiến cứu thực hiên tai Khoa hồi sức tích cực và chống độc BV Đa Khoa Trung ương Cần Thơ từ tháng 10/2020 đến tháng 03/2021 trên 185 người bệnh hôn mê. Mục tiêu là (1) Mô tả đặc điểm lâm sàng, cân lâm sàng, tình trang loét của người bệnh hôn mề tại Khoa hồi sức tích cực và chống độc Bệnh viện Đa Khọa Trung ương Cần Thơ (2) Phân tích kết quả chăm sóc người bệnh và một số yếu tố liên quan. Kết quả cho thấy người bệnh hôn mê có số ngày nằm viện trung bình là: $8,48 \pm 1,61$, tỷ lệ người bệnh có loét chiếm $26,5 \%$, không loét $73,5 \%$, có một vết loét chiếm $32,4 \%$, có 2 vết loét chỉ có

${ }^{1}$ Bệnh viện $Đ K T W$ Cần Tho

${ }^{2}$ Trường ĐH Thăng Long

Chịu trách nhiệm chính: Trương Thanh Phong

Email: truongthanhphong5318@gmail.com

Ngày nhận bài: 15.3.2021

Ngày phản biên khoa hoc: 13.5.2021

Ngày duyệt bài: 20.5.2021

\section{Trương Thanh Phong1, Dương Thị Hòa ${ }^{2}$}

4,3\%, loét độ I chiếm 56,6\% và loét độ II là 43,4\%. Về hoạt động chăm sóc vết loét trong 7 ngày: $\leq$ 1lần/ngày chiếm tỷ lệ cao từ $84,3 \%$ đển $89.2 \%$. Về thay đổi tư thế và xoa bóp vùng tỳ đè $\geq 3$ lần/ngày chiếm tỷ lệ cao từ $87,3 \%$ đến $96.2 \%$. Kết quả cho thây, sư khác biêt có ý nghĩa thống kê giữa nhóm ngưới bênh có BMI bình thường và BMI béo phì với kết quả chăm sóc $(p<0,05)$, giữa người bệnh có bênh bị đái tháo đường và người bệnh không bị bệnh đái tháo đường với kết quả chăm sóc $(p<0,05)$, giữa người bệnh có thời gian nằm viện $>7$ ngày và $\leq 7$ ngày với kết quả chăm sóc $(p<0,05)$, giữa người bệnh có sử dụng nệm hơi và không sử dung nệm hơi với kết quả chăm sóc, $(\mathrm{p}<0,05)$. Tuy nhiển, chưa tìm thấy sự khác biệt giữa nam và nữ với với kết quả chăm sóc $p>0,0 \dot{5}$.

Tư khóa: bệnh nhân hôn mê, loét tỳ, vết loét, độ loét, chăm sóc, điều dưỡng.

\section{SUMMARY \\ SITUATION PRESSURE ULCERS AND A NUMBER OF FACTORS RELATED TO THE}




\section{PATIENT IN A COMA IN INTENSIVE CARE DEPARTMENT AND ANTITRUST CENTRAL GENERAL HOSPITAL IN CAN THO}

A prospective descriptive study was carried out at the Intensive Care and Poison Control Department of Can Tho Central General Hospital from October 2020 to March 2021 on 185 patients in coma. Objectives are (1) Describe the clinical, paraclinical, and ulcer conditions of the comatose patients at the Intensive Care and Poison Control Department of Can Tho Central General Hospital (2) Analyze the income of care patients and related factors. The results showed that the average number of days in hospital is: $8.48 \pm$ 1.61 , the proportion of patients with ulcers accounted for $26.5 \%$, without ulcers $73.5 \%$. Patients with one ulcer account for 32.4 , two ulcers only $4.3 \%$, ulcer level I 56,6 \% and level II ulcer 43,4\% . Regarding ulcer care 1 time/day accounted for a high proportion from $84.3 \%$ to $(89.2 \%)$, about changing position and massaging pressure area 3 times/day accounted for a high proportion from $87,32 \%$ to $96,2 \%$. The results showed that there was a statistically significant difference between the group with normal BMI and obese BMI with the income of care $(p<0.05)$, between patients with diabetes and patients without diabetes with care income $(p<0.05)$, the difference and statistically significant between hospital stay $>7$ days and $\leq 7$ days with the results of pressure ulcer care $(p<0.004)$, between patients using air mattress and not using air mattress and the income of care ( $p$ $<0.05)$. However, no difference was found between men and women with $\mathrm{p}>0.05$.

Keywords: comatose patients, pressure ulcer, ulcer, degree of ulcer, care, nursing.

\section{I. ĐẶT VẤN ĐỀ}

Người bệnh hôn mê có mất tri giác thường phải đối mặt với nguy cơ loét do tỳ đè. Loét tỳ đè là một tổn thương da và tổ chức giữa vùng xương với vật có nền cứng, là hậu quả của quá trình tỳ đè kéo dài gây thiếu máu nuôi tổ chức và chết tế bào gây loét. Mỗi năm có hơn 1,6 triệu người bệnh trên thế giới bị loét khi nằm viện [1], tỷ lệ loét ở các khoa phòng trung bình $10 \%-15 \%$ và ở các khoa Hồi sức cấp cứu từ $30 \%-60 \%$ [3]. Loét là một trong những nguyên nhân hàng đâuu kéo dài thời gian nằm viện, làm tăng chi phí điều trị, tăng thời gian chăm sóc và là một trong những nguyên nhân chính gây tăng tỷ lệ tử vong. Những người bệnh bị loét trong vòng 6 tuần khi nằm viện thì nguy cơ tử vong tăng gấp 3 lần so với những người bệnh không bị Loét [3]. Tại Pháp mổi năm có khoảng 400.000 người bệnh bị loét tỳ chiếm $8-20 \%$ người bệnh nội trú, chi phí điêu trị ước tính 15.000 đến 60.000 euro/người [4]. Loét do tỳ đè là một biến chứng thường gặp ở những người bệnh nằm bất động như: chấn thương cột sống, tai biến mạch máu não, gãy hai chi dưới, đái tháo đường, bỏng, bệnh nhân đa chấn thương... Chính vì vậy loét là vấn đề đang được quan tâm hàng đầu ở tất cả các bệnh viện trên thế giới, đặc biệt là tại khoa Hồi Sức Cấp cứu vì thường xuyên có nhiều người bệnh nặng, người cao tuổi, vận động kém, hôn mề,... Bệnh viện Đa Khoa Trung Ương Cần Thơ thường xuyên điều trị chuyên sâu nhiều người bệnh hôn mê thở máy nặng, có nguy cơ loét tỳ đè cao. Việc dự phòng chăm sóc loét tỳ đè đã và đang là một ưu tiên trong công tác điều dưỡng của bệnh viện. Tuy nhiên, những yếu tố nào có thể ảnh hưởng đến loét do tỳ đè, thực tế chăm sóc và điều trị như thế nào, đó là lý do đề tài chúng tôi tiến hành thực hiện đề tài khảo sát "Thực trạng loét do tỳ đè và môt số yếu tố liên quan ở người bệnh hôn mê tại khoa Hồi sức Tích cực và Chống độc BV Đa Khoa Trung ương Cần Thơ" được tiến hành nghiên cứu với 2 mục tiêu:

1. Mô tả đặc điểm lầm sàng, cận lâm sàng, tinh trạng loét của người bệnh hôn mê tại Khoa hồi sức tích cực và chống độc BV Đa Khoa Trung ương Cần Thớ.

2. Phân tích kết quả chăm sóc và một số yếu tố liên quan.

\section{II. ĐỐI TƯỢNG VÀ PHƯƠNG PHÁP NGHIÊN CỨU \\ 1. Đối tượng nghiên cứu.}

Tiêu chuấn lựa chọn: Người bệnh hôn mê điều trị tại khoa Hổi sức tích cực - Chống độc.

Thời gian: từ 10/2020 đến tháng 03/2021.

2. Thiết kế nghiên cứu: Nghiên cứu mô tả tiến cứu.

3. Cỡ mẫu: Tổng số 185 người bệnh hôn mê tại khoa Hồi sức tích cực và Chống độc.

4. Biến số nghiển cứu: Tuổi, giới, nghề nghiệp, trình độ học vấn, nghề nghiệp, nơi cư trú, BMI, số ngày nằm điều trị, hôn nhân, bệnh lý mạn tính kèm theo, thời gian nằm viện, thời gian thở máy, tri giác, mạch, Huyết áp, Nhiệt độ, bất thường ,vị trí vùng loét, thời gian xuất hiện loét, nguy cơ loét theo Braden, số lượng vết loét, mức độ tổn thương, tình trạng loét khi rời khoa.

5. Xử lý số liệu: Phân tích, xử lý bằng phần mềm SPSS 20.0 tính tỷ lệ phần trăm, phân tích đơn biến các yếu tố tìm khác biệt có ý nghĩa thống kê khi $p<0,05$.

\section{KẾT QUẢ NGHIÊN CỨU} cứu.

1. Đặc điểm chung của đối tượng nghiên

Bảng 1: Phân bố đôi tượng nghiên cứu. \begin{tabular}{|l|l|l|}
\hline Biến số nghiên cứu & n (185) & Tỷ lệ (\%) \\
\hline
\end{tabular}

\begin{tabular}{|c|c|c|}
\hline \multicolumn{3}{|c|}{ Nhóm tuối } \\
\hline $15-41$ & 19 & 10,3 \\
\hline
\end{tabular}


VIETNAM MEDICAL JOURNAL N ${ }^{0} 1$ - JUNE - 2021

\begin{tabular}{|c|c|c|c|}
\hline \multicolumn{2}{|c|}{$41-60$} & 34 & 18,4 \\
\hline \multicolumn{2}{|c|}{$>60$} & 132 & 71,3 \\
\hline \multicolumn{2}{|c|}{ Giới tính: Nam } & 103 & 55,7 \\
\hline \multicolumn{2}{|c|}{ Nữ } & 82 & 44,3 \\
\hline \multicolumn{2}{|c|}{ Nơi cư trú: Thành thị } & 53 & 28,6 \\
\hline \multicolumn{2}{|c|}{ Nông thôn } & 132 & 71,4 \\
\hline \multicolumn{2}{|c|}{ BMI: $<18,5$} & 17 & 9,2 \\
\hline \multicolumn{2}{|c|}{$18,5-22,9$} & 121 & 65,4 \\
\hline \multicolumn{2}{|c|}{$\geq 23$} & 47 & 25,4 \\
\hline \multicolumn{4}{|c|}{ Số ngày nằm viện } \\
\hline \multicolumn{2}{|c|}{$\leq 7$ ngày } & 67 & 36,2 \\
\hline \multicolumn{2}{|c|}{$>7$ ngày } & 118 & 63,8 \\
\hline \multicolumn{4}{|c|}{ Số ngày nắm viện trung bình: $8,48 \pm 1,61$} \\
\hline \multicolumn{4}{|c|}{ Thời gian thở máy } \\
\hline \multicolumn{2}{|c|}{ Không thở máy } & 20 & 10,8 \\
\hline \multicolumn{2}{|c|}{$\leq 7$ ngày } & 77 & 41,6 \\
\hline \multicolumn{2}{|c|}{$>7$ ngày } & 88 & 47,6 \\
\hline \multicolumn{4}{|c|}{ Số ngày trung bình thở máy: 7,04 13,23} \\
\hline \multicolumn{4}{|c|}{ Bệnh lý kèm theo } \\
\hline \multicolumn{2}{|c|}{ Bệnh đái tháo đường } & 48 & 25,9 \\
\hline \multicolumn{2}{|c|}{ Bệnh tim mạch } & 101 & 54,6 \\
\hline \multicolumn{2}{|c|}{ Bệnh hô hấp } & 14 & 7,6 \\
\hline \multicolumn{2}{|c|}{ Bệnh thân kinh } & 2 & 1,1 \\
\hline \multicolumn{4}{|c|}{ 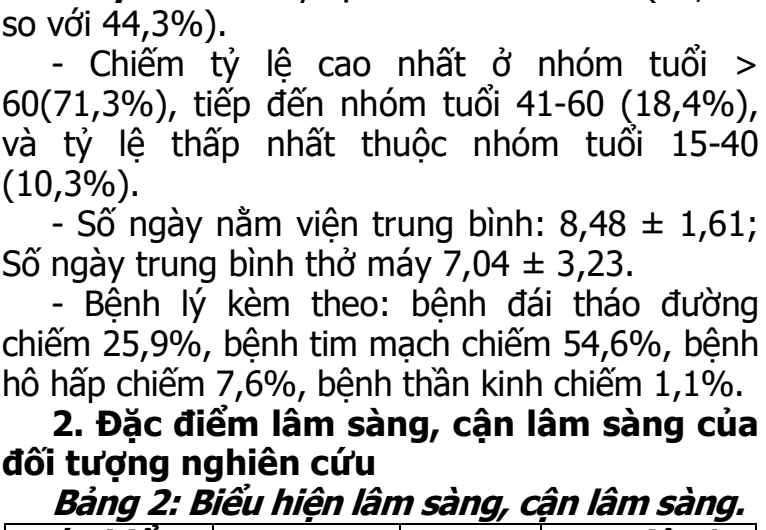 } \\
\hline $\begin{array}{l}\text { Các biếu } \\
\text { hiện lâm } \\
\text { sàng }\end{array}$ & Ngày 1 & Ngày 3 & $\begin{array}{c}\text { Ra viện/ } \\
\text { chuyển } \\
\text { khoa }\end{array}$ \\
\hline \multicolumn{4}{|c|}{ Sốt } \\
\hline Cao & $\begin{array}{c}112 \\
(60,5 \%)\end{array}$ & $\begin{array}{c}105 \\
(56,8 \%)\end{array}$ & $95(51,4 \%)$ \\
\hline \multicolumn{4}{|c|}{ Mạch } \\
\hline Bất thường & 153 & 137 & $118(64,3 \%)$ \\
\hline
\end{tabular}

\begin{tabular}{|c|c|c|c|}
\hline & $(83,8 \%)$ & $(74,1 \%)$ & \\
\hline Bình thường & $30(16,2 \%)$ & $\begin{array}{c}30 \\
(25,9 \%)\end{array}$ & $66(35,7 \%)$ \\
\hline \multicolumn{4}{|c|}{ Huyết áp } \\
\hline Cao & $45(24,3 \%)$ & $\begin{array}{c}19 \\
(10,3 \%)\end{array}$ & $6(3,2 \%)$ \\
\hline Bình thường & $\begin{array}{c}106 \\
(57,3 \%)\end{array}$ & $\begin{array}{c}161 \\
(87,0 \%)\end{array}$ & $167(90,3 \%)$ \\
\hline Thấp & $34(18,4 \%)$ & $5(2,7 \%)$ & $12(6,5 \%)$ \\
\hline $\begin{array}{l}\text { Kết quả cận } \\
\text { lâm sàng }\end{array}$ & Vào viện & & Ra viện \\
\hline \multicolumn{4}{|c|}{ Hemoglobin } \\
\hline Bình thường & $60(32,5 \%)$ & & $33(17,8 \%)$ \\
\hline Bất thường & $\begin{array}{c}125 \\
(67,5 \%)\end{array}$ & & $152(82,2 \%)$ \\
\hline \multicolumn{4}{|c|}{ Bạch câu } \\
\hline Bình thường & $53(28,6 \%)$ & & $49(26,5 \%)$ \\
\hline Bất thường & $132(71,4 \%)$ & & $136(73,5 \%)$ \\
\hline \multicolumn{4}{|c|}{ Đường huyết } \\
\hline Bình thường & $53(28,6 \%)$ & & $78(42,2 \%)$ \\
\hline Bất thường & $\begin{array}{c}132 \\
(71,4 \%)\end{array}$ & & $107(57,8 \%)$ \\
\hline \multicolumn{4}{|c|}{ Albumin } \\
\hline Bình thường & $35(18,9 \%)$ & & $52(28,1 \%)$ \\
\hline Bất thường & $\begin{array}{c}150 \\
(81,1 \%) \\
\end{array}$ & & $133(71,9 \%)$ \\
\hline
\end{tabular}

Nhận xét:

Về lâm sàng:

> Người bệnh có sốt: vào viện chiếm 60,5\%, khi ra viện còn $(51,4 \%)$

> Mạch bất thường: vào viện chiếm $82,7 \%$, khi ra viện còn $63,8 \%$.

$>$ Chỉ số huyết áp cao: vào viện chiếm $24,3 \%$, ra viện còn $(3,2 \%)$, huyết áp hạ: khi vào viện là $18,4 \%$, ra viện còn $(6,5 \%)$.

Về Kết quả cận lâm sàng:

> Hemoglobin bất thường: vào viện chiếm $67,5 \%$, ra viện chiếm $82,2 \%$.

$>$ Bạch câu bất thường vào: viện chiếm $71,4 \%$, ra viện chiếm 73,5\%.

$>$ Đường huyết bất thường: vào viện chiếm $71,3 \%$, ra viện còn 57,8

$>$ Albumin bất thường: vào viện chiếm $81,1 \%$, ra viện còn $71,9 \%$.

Bảng 3: Tình trạng loét của người bệnh trong quá trình điều trị chăm sóc.

\begin{tabular}{|c|c|c|c|c|c|c|c|}
\hline \multirow{2}{*}{$\begin{array}{c}\text { NB } \\
\text { loét }\end{array}$} & \multicolumn{6}{|c|}{ Người bệnh hôn mê có loét trong quá trình đî̀u trị chăm sóc (n= 185) } \\
\cline { 2 - 8 } & Ngày 1 & Ngày 2 & Ngày 3 & Ngày 4 & Ngày 5 & Ngày 6 & Ngày 7 \\
\hline Có & $21(11,3 \%)$ & $41(22,2 \%)$ & $60(32,4 \%)$ & $63(34,1 \%)$ & $59(31,9 \%)$ & $49(26,5 \%)$ & $49(26,5 \%)$ \\
\hline Không & $163(88, \%)$ & $144(77,8 \%)$ & $125(67,6 \%)$ & $122(65,9 \%)$ & $126(68,1 \%)$ & $136(73,5 \%)$ & $136(73,5 \%)$ \\
\hline
\end{tabular}

Nhận xét: Loét ngày 1 chiếm tỷ lệ $11,9 \%$, ngày thứ 3 chiếm $32,4 \%$ và khi ra viện chiếm tỷ lệ $27,6 \%$. Thời điểm người bệnh có loét ngày thứ 3,4,5 chiếm tỷ lệ cao nhất :32,4\%,34,1\%, 31,9\% và ngày thứ 7 chiếm 26,5\%. 
Bảng 4: Thức trạng vêt loét và mức độ loét trên người bệnh.

\begin{tabular}{|c|c|c|}
\hline \multirow{2}{*}{ Biến số nghiên cứu } & \multicolumn{2}{|c|}{$\begin{array}{c}\text { Người bệnh hôn mên } \\
\text { (n = 185) }\end{array}$} \\
\cline { 2 - 3 } & Số lượng & Tỷ lệ (\%) \\
\hline Số lượng vết loét: & & \\
\hline 1 vết & 60 & 32,4 \\
\hline 2 vết & 8 & 4,3 \\
\hline
\end{tabular}

\begin{tabular}{|c|c|c|}
\hline Mức độ loét: & & \\
\hline Loét độ I & 43 & $23,24 \%$ \\
\hline Loét độ II & 33 & $17,83 \%$ \\
\hline
\end{tabular}

Nhận xét: Người bênh có 1 vết loét chiếm tỷ lệ $32,4 \%$, có 2 vết loét chiếm tỷ lệ $(4,3 \%)$. Loét độ I chiếm tỷ lệ cao hơn độ II $(23,24 \%$ so với $17,83 \%)$.

3. Hoạt động chăm sóc người bệnh

Bảng 5: Môt số hoạt động chăm sóc dự phòng loét.

\begin{tabular}{|c|c|c|c|c|c|c|c|}
\hline Biến số & Ngày 1 & Ngày 2 & Ngày 3 & Ngày 4 & Ngày 5 & Ngày 6 & Ngày 7 \\
\hline \multicolumn{8}{|c|}{ Chăm sóc vết loét } \\
\hline$\leq 1$ lân/ngày & $165(89,2 \%)$ & $163(88,1 \%)$ & $160(86,5)$ & $158(85,4 \%)$ & $157(84,9 \%)$ & $156(84,3 \%)$ & $157(84,9 \%)$ \\
\hline z2lân/ngày & $20(10,8 \%)$ & $22(11,9 \%)$ & $25(13,5 \%)$ & $27(14,6 \%)$ & $28(15,1 \%$ & $29(15,7 \%)$ & $28(15,1 \%)$ \\
\hline \multicolumn{8}{|c|}{ Thay đối tư thế và xoa bóp vùng tỳ đè } \\
\hline 2 lân/ngày & $6(3,2 \%)$ & $5(2,7 \%)$ & $5(2,7 \%)$ & $5(2,7 \%)$ & $6(3,2 \%)$ & $6(3,2 \%)$ & $7(3,8 \%)$ \\
\hline z3lần/ngày & $179(96,8 \%)$ & $180(97,3 \%)$ & $180(97,3)$ & $180(97,3 \%)$ & $179(96,8 \%)$ & $179(96,8 \%)$ & $178(96,2 \%)$ \\
\hline \multicolumn{8}{|c|}{ Sử dụng đệm hơi } \\
\hline Có & $87(47 \%)$ & $87(47 \%)$ & $87(47 \%)$ & $87(47 \%)$ & $87(47 \%)$ & $87(47 \%)$ & $87(47 \%)$ \\
\hline Không & $98(53 \%)$ & $98(53 \%)$ & $98(53 \%)$ & $98(53 \%)$ & $98(53 \%)$ & $98(53 \%)$ & $98(53 \%)$ \\
\hline \multicolumn{8}{|c|}{ Sử dụng dung dịch chống loét } \\
\hline s1lân/ngày & $11(5,9 \%)$ & $8(4,3 \%)$ & $9(4,9 \%)$ & $9(4,9 \%)$ & $7(3,8 \%)$ & $7(3,8 \%)$ & $7(3,8 \%)$ \\
\hline z2lân/ngày & $174(94,1 \%$ & $177(95,7 \%)$ & $176(95,1 \%)$ & $176(95,1 \%)$ & $178(96,2 \%)$ & $178(96,2 \%)$ & $178(96,2 \%)$ \\
\hline \multicolumn{8}{|c|}{ Tỷ lệ loét tỳ } \\
\hline Có & loét & & 49 & & & $26,5 \%$ & \\
\hline Khôn & g loét & & 136 & & & 73,5 & \\
\hline \multicolumn{8}{|c|}{ Kết quả chăm sóc } \\
\hline & c tốt & & 128 & & & 69,2 & \\
\hline Mức khá/ & Trung bình & & 57 & & & 30,8 & \\
\hline
\end{tabular}

Nhân xét:

$>$ Về chăm sóc vết loét : $\leq 1$ lần/ngày vào ngày 1 chiếm tỷ lệ cao là $89,2 \%$ và đến ngày thứ 7 là $84.9 \%$; $\geq 2$ lần/ngày vào ngày 1 chiếm tỷ lệ $10,8 \%$ và đến thứ ngày 7 là $15.1 \%$.

> Vê thay đổi tư thế và xoa bóp vùng tỳ đè: 2lần/ngày vào ngày 1 chỉ chiếm $3,2 \%$ và vào ngày thứ 7 tăng $3,8 \% ; \geq 3$ lân/ngày ở vào ngày 1 chiếm $96,8 \%$ và vào ngày thứ 7 chiếm $96,2 \%$.

> Người bệnh có sử dụng đệm hơi: Ngày 1 đến ngày thứ 7 đều chiếm $47 \%$; không sử dụng đệm hơi: Ngày 1 đến ngày thứ 7 đều chiếm $53 \%$.

Sử dung dung dịch chống loét : $\leq 1$ lần/ngày ngày 1 chiếm $5,9 \%$, ngày thứ 7 chiếm $3,8 \% ; \geq 2$ lần/ngày vào ngày thứ nhất chiếm $94,1 \%$ và vào ngày thứ 7 chiếm $96,2 \%$.

> Tỷ lệ loét tỳ: có loét chiếm tỷ lệ $26,5 \%$, không loét chiếm 73,5\%.

$>$ Kết quả chăm sóc: Mức tốt chiếm 69,2\%; Mức khá/trung bình chiếm 30,8\%.

4. Một số yếu tố liên quan đến kết quả chăm sóc người bệnh hôn mê.

Bảng 6: Liên quan giữa đặc điểm chung với kêt quả chăm sóc.

\begin{tabular}{|c|c|c|c|c|c|}
\hline \multicolumn{2}{|c|}{ Biến số nghiên cứu } & Mức tốt & Mức khá/TB & OR & p \\
\hline \multicolumn{6}{|c|}{ Mối liên quan giữa đặc điểm chung với kết quả chăm sóc. } \\
\hline \multirow{2}{*}{ Giới tính } & Nam & $73(70,9 \%)$ & $30(29,1 \%)$ & \multirow{2}{*}{$\begin{array}{c}1,195 \\
(0,64-2,24)\end{array}$} & \multirow[b]{2}{*}{0,578} \\
\hline & Nữ & $55(67,1 \%)$ & $27(32,9 \%)$ & & \\
\hline \multirow{2}{*}{ Nơi ở } & Nông thôn & $101(76,5 \%)$ & $31(23,5 \%)$ & \multirow{2}{*}{$\begin{array}{c}3,134 \\
(1,60-6,13)\end{array}$} & \multirow{2}{*}{0,001} \\
\hline & Thành & $27(50,9 \%)$ & $26(49,1 \%)$ & & \\
\hline \multirow{2}{*}{ BMI } & Bình thường & $90(53,57 \%)$ & $31(18,4 \%)$ & \multirow{2}{*}{$\begin{array}{c}1,988 \\
(1,04-3,79)\end{array}$} & \multirow{2}{*}{0,035} \\
\hline & Béo phì & $38(22,6 \%)$ & $9(5,4 \%)$ & & \\
\hline \multicolumn{6}{|c|}{ Mối liên quan giữa thời gian nằm viện với kết quả chăm sóc } \\
\hline \multirow{2}{*}{ Thời gian nằm viện } & $>7$ ngày & $11(52,4 \%)$ & $10(47,6 \%)$ & \multirow{2}{*}{$\begin{array}{c}3,649 \\
1,44-9,26\end{array}$} & \multirow{2}{*}{0,004} \\
\hline & $\leq 7$ ngày & $38(23,2 \%)$ & $126(76,8 \%)$ & & \\
\hline \multicolumn{6}{|c|}{ h lý kèm theo với kết quả chăm sóc. } \\
\hline Bênh nội tiết & Có & $25(52,1 \%)$ & $23(47,9 \%)$ & 2,786 & 0,003 \\
\hline
\end{tabular}


VIETNAM MEDICAL JOURNAL N ${ }^{0} 1$ - JUNE - 2021

\begin{tabular}{|c|c|c|c|c|c|}
\hline & Không & $103(75,2 \%$ & $34(24,8 \%)$ & $(1,40-5,52)$ & \\
\hline \multirow{2}{*}{ Bệnh tim mạch } & Có & $73(72,3 \%)$ & $28(27,7 \%)$ & \multirow{2}{*}{$\begin{array}{c}1,375 \\
(0,74-2,57)\end{array}$} & \multirow{2}{*}{0,319} \\
\hline & Không & $55(65,5 \%)$ & $29(34,5 \%)$ & & \\
\hline \multicolumn{6}{|c|}{ Mối liên quan giữa Albumin máu với kết quả chăm sóc . } \\
\hline \multirow{2}{*}{ Albumin máu } & Bình thường & $30(85,7 \%)$ & $5(14,3 \%)$ & \multirow{2}{*}{$\begin{array}{c}3,184 \\
(1,17-8,70)\end{array}$} & \multirow{2}{*}{0,018} \\
\hline & Thấp & $98(65,3 \%)$ & $52(34,7 \%)$ & & \\
\hline \multicolumn{6}{|c|}{ Môii liên quan giữa mức độ nguy cơ loét theo Braden với kết quả chăm sóc } \\
\hline \multirow{2}{*}{$\begin{array}{c}\text { Mức độ nguy cơ theo } \\
\text { Braden }\end{array}$} & Thấp/Trungbình & $68(77,3 \%)$ & $20(22,7 \%)$ & \multirow{2}{*}{$\begin{array}{c}2,097 \\
(1,10-3,99)\end{array}$} & \multirow{2}{*}{0,023} \\
\hline & Cao/rất cao & $60(61,9 \%)$ & $37(38,1 \%)$ & & \\
\hline \multicolumn{6}{|c|}{ Mối liên quan giữa hoạt đông dư phòng chăm sóc với kết qu } \\
\hline \multirow{2}{*}{$\begin{array}{l}\text { Sử dụng dung dịch } \\
\text { chống loét }\end{array}$} & $\geq 2$ lân/ngày & $124(71,3 \%)$ & $50(28,7 \%)$ & \multirow{2}{*}{$\begin{array}{c}4,340 \\
(1,2-15,4)\end{array}$} & \multirow{2}{*}{0,015} \\
\hline & $\leq 1$ lân/ngày & $4(36,4 \%)$ & $7(63,6 \%)$ & & \\
\hline \multirow{2}{*}{ Sử dụng nệm hơi } & Có & $68(78,2 \%)$ & $19(21,8 \%)$ & \multirow{2}{*}{$\begin{array}{c}2,267 \\
(1,18-4,34)\end{array}$} & \multirow{2}{*}{0,012} \\
\hline & Không & $60(61,2 \%)$ & $38(38,8 \%)$ & & \\
\hline \multirow{2}{*}{$\begin{array}{l}\text { Thay đối tư thế và } \\
\text { xoa bóp vùng tỳ đè }\end{array}$} & $\geq 3$ lân/ngày & $127(70,9 \%)$ & $52(29,1 \%)$ & \multirow{2}{*}{$\begin{array}{c}12,2 \\
(1,39-107,1)\end{array}$} & \multirow{2}{*}{0,017} \\
\hline & $\leq 2$ lân/ngày & $1(16,7 \%)$ & $5(83,3 \%)$ & & \\
\hline
\end{tabular}

Nhận xét:

$>$ Chưa tìm thấy sự khác biêt và có ý nghĩa thống kê giữa nam và nữ với kểt quả chăm sóc, $\mathrm{p}>0,05$.

$>$ Có sự khác biệt và có ý nghĩa thống kê giữa nhóm người bệnh ở thành thị và nông thôn ( $p<0.05)$, giữa người bệnh có $B M I$ bình thường và $B M I$ béo phì với kết quả chăm sóc $(p<0,05)$, giữa người bệnh có thời gian nằm viện $>7$ ngày và $<7$ ngày với kết quả chăm sóc $(p<0,05)$.

$>$ Có sự khác biệt có ý nghĩa thống kê: giữa nhóm người bệnh có bệnh nội tiết và không mắc bệnh nội tiết với kết quả chăm sóc $(p<0,05)$, giữa nhóm người bệnh có Albumin máu thấp và bình thường với kết quả chăm sóc $(p<0,05)$, giữa mức độ nguy cơ loét theo Braden mức thấp/trung bình và nguy cơ cao/rất cao với kết quả chăm sóc $(p<0,05)$. Chưa tìm thây sự khác biêt có ý nghĩa thống kê giữa nhóm người bênh kèm bệnh tim mạch và không mắc kèm bệnh tim mạch với kết quả chăm sóc $(p>0,05)$.

$>$ Có sự khác biệt có ý nghĩa thống kê: giữa người bệnh có sử dụng nệm hơi và không sử dụng nệm hơi với kết quả chăm sóc, $p<0,05$, giữa người bệnh có thay đổi tư thế $\geq 3$ lần/ngày và $\leq 2$ lần/ngày với kết quả chăm sóc, $p<0.05$, giữa người bệnh có sử dụng dung dịch chống loét $\geq 2$ lần/ngày $\leq 1$ lần/ngày với kết quả chăm sóc, $\mathrm{p}<0,05$.

\section{BÀN LUÂ̂N}

1. Đặc điểm của đối tượng nghiên cứu: Nghiên cứu được tiến hành trên tổng số 185 người bệnh, trong đó có $103(55,7 \%)$ người bệnh nam và $82(44,3 \%)$ người bệnh nữ, kết quả này gần tương đồng với nghiên cứu của Vũ Thị Kim Định, khoa hồi sức tích cực Bệnh Viện Đa Khoa Thanh Nhàn [3]. Nghiên cứu cho thấy nhóm tuổi > 60(71,3\%) chiếm tỷ lệ cao nhất. Kết quả này tương đồng nghiên cứu của Trần Hồng Huệ tại bệnh viện Nguyễn Tri Phương [3].

\section{Thực trạng Người bệnh hôn mê:}

Kết quả nghiên cứu cho thấy: Ngày 1 có 11,9\% người bệnh nhập viện trong tình trạng có loét do người bênh được chuyển từ tuyến dưới lên đã có sẵn yếu tố nguy cơ loét trong $24 \mathrm{~h}$ đầu. Loét ngày thứ $3,4,5$ chiếm tỷ lệ cao nhất: $32,4 \%, 34,1 \%, 31,9 \%$ đến ngày thứ 7 giảm còn $26,5 \%$, tỷ lê loét đã giảm được 5,2\% do bênh viện đã có những biện pháp phòng ngừa và áp dụng các biện pháp chăm sóc tích cực.

Thời điểm người bệnh có loét: ngày thứ $3,4,5$ chiếm tỷ lệ: $32,4 \%, 34,1 \%, 31,9 \%$, kết quả này tương đồng với nghiên cứu của Nguyễn Thế Bình bệnh viện Việt Đức. Thời gian nằm viện càng lâu, người bệnh càng gầy, thể trạng càng kém thì nguy cơ loét tỳ đè càng cao [2]. Thời gian xuất hiện loét luôn có từ ngày đầu đến ngày thứ 7 . Tuy nhiên không tương đồng so với kết quả nghiên cứu của Lê Thị Trang tại bệnh viện Bạch Mai với thời gian xuất hiện loét sớm nhất là 2 ngày và muôn nhất 4 ngày [2].

Về tỷ lệ loét: Người bệnh có loét chiếm $26,5 \%$, kết quả của chúng tồi thấp hơn so với nghiên cứu của Nguyễn Thế Bình và Trần Văn Oánh ( $26,5 \%$ so với $31,4 \%$ và $41,7 \%$ ) [2]; điêu này có thể giải thích rằng người bệnh hôn mê do bệnh lý nội khoa thì việc chăm sóc, thay đổi tư thế , xoa bóp vùng tỳ đè sẽ thuận lợi hơn so với người bệnh mổ chấn thương cột sống ngực thắt lưng có liệt tủy tại khoa chẩn thương chỉnh hình bệnh viện Việt Đức [2].

Số lượng và vị trí loét : Người bênh có 1 vết loét chiếm 32,4\%, 2 vết loét chiếm $4,3 \%$, chiếm cao nhất là vùng cùng cụt $(81,6 \%)$. Kết 
quả này thấp hơn so với nghiên cứu của Nguyễn Thế Bình với loét vùng cùng cụt chiếm $83,34 \%$ [2] và cao hơn so với Lê Thị Trang với loét cùng cụt chiếm 46,6\% [2].

Mức độ loét: độ I chiếm $56,6 \%$ và độ II là $43,4 \%$. Kết quả không tương đồng so với nghiên cứu của Lê Thị Trang tại khoa chấn thương chỉnh hình và cột sống Bệnh viện Bạch Mai với loét độ I chiếm 26,6\%, độ II chiểm 73,4\% [2]

\section{Về hoạt động chăm sóc người bệnh:}

Về số lần chăm sóc vết loét: $\leq 1$ lần/ngày ngày 1 chiếm tỷ lệ cao từ $(89,2 \%)$ và đến ngày thứ 7 là $84,9 \%$. Số lần chăm sóc vết loét $\geq$ 2lần/ngày vào ngày nhất chiếm tỷ lệ $10,8 \%$ và đến thứ 7 là $15,1 \%$ kết quả này cũng tương đồng với Nguyễn Thanh Bình về hoạt động chăm sóc người bệnh loét tại BVĐK Xanh Pôn [1].

Vê thay đổi tư thế và xoa bóp vùng tỳ đè: 2 lần/ngày ngày 1 chiếm $3,2 \%$ và ngày thứ 7 chiếm $3,8 \%$, $\geq 3$ lần/ngày ở vào ngày 1 chiếm $96,8 \%$ và vào ngày thứ 7 chiếm $96,2 \%$. Có sự khác biệt và ý nghĩa thống kê giữa người bệnh có thay đổi tư thế với kết quả chăm sóc, $\mathrm{p}<$ 0,05 . Kết quả cho thây thay đổi tư thế $\geq 3$ lần/ngày cho kết quả chăm sóc tốt hơn so với 2 lần/ngày (70,9\% so với 16,7\%).

Về sử dụng dung dịch chống loét và đệm hơi: Sử dụng dung dịch chống loét: $\leq 1$ lần/ngày ngày 1 chiếm $5,9 \%$, ngày thứ 7 chiếm $3,8 \%$; $\geq$ 2lần/ngày vào ngày 1 chiếm $94,1 \%$ đến ngày thứ 7 chiếm 96,2. Người bệnh có sử dụng đệm hơi từ ngày 1 đến ngày 7 đều chiếm thấp $47 \%$, không sử dụng đệm hơi chiếm cao $53 \%$. Sự khác biệt và có ý nghĩa thống kê giữa người bệnh có sử dụng dung dịch chống loét $\geq 2$ lần/ngày và $\leq 1$ lần/ngày với kết quả chăm sóc, $p<0,05$, giữa sử dụng đệm hơi và không có dùng đệm hơi với loét tỳ $(p<0,05)$. Việc sử dụng đệm hơi thì nguy cơ loét cũng ít xảy ra so với không dùng đệm hơi. Do đó việc tư vấn giáo dục sức khỏe rất quan trọng để phòng ngừa loét tỳ [4].

Tỷ lệ người bệnh sau 7 ngày chăm sóc: có loét chiếm tỷ lệ $26,5 \%$, không loét chiếm $73,5 \%$, điều này cho thấy hiệu quả của điều dưỡng viên chăm sóc và các biện pháp can thiệp giúp giảm nguy cơ loét.

Về phân loại kết quả chăm sóc: Mức tốt chiếm 69,2\%; Mức khá/trung bình chiếm 30,8\%.

4. Một số yếu tố liên quan: Có sự khác biệt và có ý nghĩa thống kê giữa nhóm người bệnh ở thành thị và nông thôn với $p<0,001$ do khi bệnh nặng gia đình người bệnh ở thành thị luôn có những điều kiện thuận lợi hơn so với nông thôn trong việc tìm kiếm sự can thiệp y tế sớm.
Có sự khác biệt có ý nghĩa thống kê giữa nhóm người bệnh có $B M I$ bình thường và $B M I$ béo phì với $p<0,05$, vì khi người bệnh hôn mê có béo phì dẫn đến hạn chế, khó khăn hơn khi vận động hoặc bất động. Kỹ thuật cũng như thời gian xoa bóp khó khăn hơn nền nguy cơ loét cao hơn so với nhóm bệnh nhân không béo phì.

Có sự khác biệt có ý nghĩa thống kê giữa người bệnh có bệnh nội tiết và người bệnh không có bệnh nội tiết với kết quả chăm sóc ( $p$ $<0,05)$. Khi người bệnh hôn mê kèm bệnh lý nội tiết (đái tháo đường..) thì khả năng miễn dịch giảm, sức đề kháng kém hơn so với người không mắc bệnh kèm theo. Có sự khác biệt và có ý nghĩa thống kê giữa thời gian nằm viện $>7$ ngày và $\leq 7$ ngày với kết quả chăm sóc $(p<0,05)$, người bệnh nằm viện kéo dài, nguy cơ nhiễm trùng cao kết hợp với thể trạng gầy, sức đề kháng kém và dinh dưỡng kém, teo cơ, cứng khớp dẫn đến nguy cơ loét cao mặc dù bệnh nhân đã được can thiệp chăm sóc tích cực.

\section{KẾT LUÂN}

1.Về đặc điểm lâm sàng, cận lâm sàng , tình trạng loét của người bệnh: Người bệnh hôn mế có sốt cao, mạch bất thường, huyết áp bất thường khi vào viện và giảm dần theo thời gian khi bệnh nhân ra viện. Thông qua kết quả cận lâm sàng cho thấy người bệnh hôn mê nặng có tình trạng thiếu máu và nhiếm trùng.

Tình trạng loét tỳ đè: Người bệnh có loét chiếm $26,5 \%$. Thời gian xuất hiện loét tỳ đè ngày $3,4,5$ chiếm tỷ lệ cao. Hầu hết bệnh nhân có xuất hiện một vết loét và nằm trong loét độ $\mathrm{I}$. Vị trí loét thường gặp nhất là vùng cùng cụt chiểm $81,6 \%$.

Hoạt động chăm sóc: Người bệnh được chăm sóc vết loét $\leq 1$ lần/ngày và được điều dưỡng thay đổi tư thế, xoa bóp vùng tỳ đè: $\geq$ 3lần/ngày, sử dụng dung dịch chống loét: $\geq 2$ lần/ngày chiếm tỷ lệ cao.

Kết quả chăm sóc: Mức tốt chiếm 69,2\%; Mức khá/trung bình chiếm 30,8\%.

2. Yếu tố liên quan đến kết quả chăm sóc loét tỳ đè. Dựa theo mô hình đánh giá nguy loét tỳ đè của Braden, người bệnh có các bệnh lý kèm theo như béo phì, đái tháo đường, thời gian nằm viện kéo dài trên 7 ngày có nguy cơ loét cao hơn so với bệnh nhân hôn mê đơn thuần. Sự khác biệt có ý nghĩa thống kê ( $p<0,05)$.

\section{TÀI LIÊU THAM KHẢO}

1. Nguyễn Thanh Bình (2020),"Kết quả chăm sóc loẹt do tỳ đè trên người bệnh chấn thương sọ não tại Bệnh viện Đa khoa Xanh Pôn năm 2020", Luận văn thăc sĩ Điều dưỡng, Trường ĐH Thăng Long.

2. Nguyễn Thế Bình (2004), "Đánh giá tình hình 
loét trên người bệnh mổ chấn thương cột sống thắt lưng và có liêt tủy tai khoa Chấn thương chỉnh hình bệnh viện Việt Đức", Khóa luận TN, Trường ĐHY Hă Nôi.

3. Lê Thị Trang, Pham Thị Kim Thoa, Hoàng Gia Du, Vũ Xuấn Phước, Nguyễn Đức Hoàng (2019),"Thực trạng loét tỳ đè trên bênh nhân chấn thương cột sống có liệt tủy tại khoa chấn thương chỉnh hình và cột sống Bênh viện Bach Mai", Tap chí y học việt nam, 2(484), tr. 244-249.

4. Phan Thi Dung (2017), "Nhâan xét phòng loét tỳ đè của điều dưỡng qua trường hợp nghiên cứu tai Bệnh viện hữu nghị Việt Đức", Tạp chí y học thảm họa và bỏng, 3(12), tr.56-59.

5. Trân Hồng Huệ, Nguyễn Thị Lan Minh
(2016), "Khảo sát loét tỳ đè ở bệnh nhân tại các phòng bệnh nặng trong bệnh viện Nguyển Tri Phương", Tạp chí y học TP Hồ Chí Minh, 3(21), tr.112-116.

6. Trân Văn Oánh, Nguyễn Thì Hằng, Chu Văn Long, Nguyễn Ngọc Thực, Nguyển Hữu Trung, Pham Thị Sơn và cộng sự (2016), "Giải pháp dự phòng loét tỳ đè trên người bệnh tại phòng hî̀i sức khoa nội- hồi sức thần kinh Bệnh viên Hà Nôi Viêtt Đức", tr 29-35.

7. Vứ Thị Kìm Định, Đào Quang Minh (2019)," Khảo sát nquy cơ loét tỳ đè và các yêu tố liến quan trên bênh nhân nội trú tại khoa hồi sức tích cực Bệnh viện Thanh Nhàn", Tạp chí y học cộng đồng", 3(50), tr.134-139.

\section{HÌNH THÁI ỐNG TỦY RĂNG SỐ 7 HÀM TRÊN CỦA NGƯỜI HÀ NộI}

\section{Pham Như Hải*, Trương Thi Mai Anh*, Nguyễn Văn Giang*, Nguyễn Thị Như Trang*}

\section{TÓM TẮT}

Chụp cắt lớp vi tính chùm tia hình nón $(\mathrm{CBCT})$ là một công cụ có giá trị cho điều trị nội nha. Mục đích của nghiên cứu này là xác định hình thái của ổng tủy răng hàm 7 hàm trên. CBCTं của 360 bệnh nhân đã được sử dụng. Kết quả như sau: Số lượng chân răng 4 $(0,4 \%), 3(91,25 \%), 2(6,94 \%), 1$ (1,4\%). 84,7\% răng chân gân ngoài chỉ có 1 ống tủy, nữ $(85,5 \%)$ cao hơn nam $(83,8 \%)$. Sự khác nhau bên phải và trái không có ý nghĩa thống kê. Chân xa và chân trong chì có 1 ống tủy từ lỗ vào ống tủy đến chóp răng. Hình thái ống tủy chữ $C$ chiếm $20,8 \%$, trong đó hình thái $B 1$ chiếm $8,9 \%$ và $A$ chiếm 7,6\%. Không khác biêt 2 bên phải trái, nhưng hay gặp ở nữ $(24,3 \%)$ hơn là ở nam $(16,6 \%)$

Tứ khóa: ống tủy, nội nha, cone-beam, răng 7 hàm trên.

\section{SUMMARY}

\section{ROOT CANAL MORPHOLOGY AND} CONFIGURATION MAXILARY SECOND MOLARS

Cone-beam computed tomographic (CBCT) imaging is a valuable tool for endodontic therapy. The aim of this study was to identify morphology of second upper molar root canal . CBCT of 360 patients were used. Results were as follows: Number of roots 4 $(0.4 \%), 3(91.25 \%), 2$ (6.94\%), 1 (1.4\%). 84.7\% of the mesio-bucal root teeth have only 1 root canal, women $(85.5 \%)$ higher than men $(83.8 \%)$, no difference on the right and left side. The distal and medial roots have only one canal from the canal entrance to the apex. The morphology of the C-

*Trường Đai hoc Y Dước-Đai hoc Quốc Gia Hà Nôi Chịu trách nhiệm chính: Phạm Như Hải

Email: phamnhuhai@yahoo.com

Ngày nhận bài: 15.3.2021

Ngày phản biên khoa hoc: 10.5.2021

Ngày duyệt bài: 20.5.2021 shaped canal accounts for $20.8 \%$, of which the B1 form accounts for $8.9 \%$ and $A$ accounts for $7.6 \%$. No difference between right and left, but more common in women $(24.3 \%)$ than in men $(16.6 \%)$.

Key words; root canal, endodontic, cone-beam computed tomographic,

\section{I. ĐĂT VẤN ĐỀ}

Chuyên nghiệp hóa trong lĩnh vực hình thái hoc tủy răng là rất quan trọng để thành công điêuu trị nội nha. Để tránh thất bại nội nha, đặc biệt trong quá trình chuẩn bị và hàn kín ống tủy, bác sĩ phải có kiến thức rộng về hình thái chân răng. Do mỗi răng đều có đăcc điểm riêng, nêu tạo ra một số lượng lớn các biến thể về số lượng và hình thái ống tủy. Những đặc điểm như vậy làm khó khăn trong việc tạo hình, làm sạch và trám bít hệ thống ống tủy ba theo 3 chiêu không gian. Thực hiện những yêu câu như vậy là cơ bản để điêuu trị nội nha thành công, và để bảo tồn lâu dài răng.

Mă̆t khác, sự hiểu biết không chính xác về tính phức tạp của hình thái ống tủy luôn dẫn đến không có phương pháp và cách thức tạo hình ống tủy phù hợp. Các thông số giải phẫu thường được mô tả trong tài liệu là răng hàm trên thứ hai có 3 chân răng và 3 ống tủy mà không nêu ra được các biến thể có thể gặp cũng như tỷ lệ để các bác sĩ lâm sàng cẩn trọng khi điều trị tủy cho bênh nhân.

Hiện nay, những tiến bộ công nghệ trong chụp phim răng trên lâm sàng đã cho phép thu được hình ảnh theo 3 chiêu không gian, cho phép mô tả chính xác, bao quát và toàn diện về hình thái răng; 